\title{
Assessment of Nitrogen Flows at Farm and Regional Level When Developing the Manure Management System for Large-Scale Livestock Enterprises in North-West Russia
}

\author{
Aleksandr Briukhanov, Eduard Vasilev*(D, Natalia Kozlova and Ekaterina Shalavina
}

check for updates

Citation: Briukhanov, A.; Vasilev, E.; Kozlova, N.; Shalavina, E. Assessment of Nitrogen Flows at Farm and Regional Level When Developing the Manure Management System for Large-Scale Livestock Enterprises in North-West Russia. Sustainability 2021, 13, 6614. https:/ / doi.org/10.3390/su13126614

Academic Editors: Jan Willem Erisman and Enrico Dammers

Received: 15 April 2021

Accepted: 3 June 2021

Published: 10 June 2021

Publisher's Note: MDPI stays neutral with regard to jurisdictional claims in published maps and institutional affiliations.

Copyright: (c) 2021 by the authors. Licensee MDPI, Basel, Switzerland. This article is an open access article distributed under the terms and conditions of the Creative Commons Attribution (CC BY) license (https:// creativecommons.org/licenses/by/ $4.0 /)$.
Federal Scientific Agroengineering Center VIM, Branch in Saint Petersburg, Filtrovskoje Shosse, 3, p.o. Tiarlevo, 196625 Saint Petersburg, Russia; nii@sznii.ru (A.B.); natalia.kozlova@sznii.ru (N.K.); shalavinaev@mail.ru (E.S.)

* Correspondence: sznii6@yandex.ru; Tel.: +7-(812)-466-57-16

\begin{abstract}
Arranging efficient manure management is the major environmental challenge in livestock farming in the Leningrad Region, with manure nitrogen being regarded as the main pollution source. The study aimed to identify the baselines for taking integrated manure management decisions towards reducing nitrogen losses applying nitrogen surplus and nitrogen use efficiency (NUE) as indicators calculated at the regional and municipal district level. At the regional level, NUE was found to be $34 \%$ and $\mathrm{N}$ surplus was $103 \mathrm{~kg} \mathrm{ha}^{-1}$. Eleven "environmentally friendly" districts had a mean NUE of $59 \%$, a mean N surplus $39.6 \mathrm{~kg} \mathrm{ha}^{-1}$ and a mean animal density $0.89 \mathrm{LSU}^{-1}$. Four districts were identified as "hot spots", with an animal density in the range from 2.6 to $67 \mathrm{LSU}^{-1}$, NUE from 1 to $37 \%$ and $\mathrm{N}$ surplus from 87 to $3082 \mathrm{~kg} \mathrm{ha}^{-1}$. A scenario was suggested for the redistribution of organic fertilisers between "hot spots" and "environmentally friendly" districts, allowing each district to increase the $\mathrm{N}$ surplus to the regional value. Nitrogen flows and measures improving NUE at the farm level through organisational activity and advanced practices were considered with the help of the "N input - N output" diagram and the example of the nitrogen flows on a pilot dairy farm.
\end{abstract}

Keywords: environmental assessment; nitrogen balance; manure utilisation; nitrogen use efficiency; dairy farm

\section{Introduction}

Agriculture is an important branch of the economy providing most of the world's food and contributing to sustainable rural development. World population growth and the rising food demand have led to agriculture intensification. Russia enhances agricultural production by establishing large-scale complexes, particularly in the livestock sector. In North-West Russia, for example, such complexes house above $90 \%$ of pigs and $98 \%$ of farm poultry. Above $40 \%$ of cattle are found on the farms with a capacity of over 1000 head [1].

Any large-scale production predictably increases environmental risks, raising public awareness of the ecological impacts of farming. In Russia, the ongoing reform of environmental legislation aims to harmonise it with the Europe's environmental legislation. In 2016, the transition to the BAT system started in all sectors of the economy, agriculture included [2,3].

The Leningrad Region is the leading subject of the Russian Federation in some areas of livestock and poultry farming. In 2018, it ranked first in egg production, second in poultry stock and fifth in poultry meat production. Large-scale enterprises with modern European-class equipment produce $90 \%$ of livestock products in the region [3].

Arranging efficient manure management is the major environmental challenge in regional intensive livestock farming. Most large pig complexes and poultry factories do not have enough agricultural land for manure application. Moreover, the Leningrad Region 
covers a part of the Baltic Sea catchment area and the farm manure management systems should comply both with the requirements of the Russian regulatory documents [4-6] and consider the recommendations of the Baltic Marine Environment Protection Commissionthe Helsinki Commission (HELCOM) [7].

Manure nitrogen as $\mathrm{NH}_{3}, \mathrm{~N}_{2} \mathrm{O}, \mathrm{NO}$ and $\mathrm{NH}_{4}+$ is regarded as the main source of environmental pollution in livestock farming. On the other hand, it is an important plant nutrient [8-10].

The reduction of nitrogen losses is a complex problem to be addressed in manure management $[8,11]$. In the environmental context, one of solutions is the use of nutrient balances with nitrogen surplus and nitrogen use efficiency (NUE) as environment performance indicators [12-14].

The distinctive features of agriculture, such as the involvement of living organisms, spatial distribution over large areas and duration of processes, make it difficult to acquire reliable data on soil and water pollution and gaseous emissions to air. Therefore, the topical research issue is the search for environmental assessment indicators and their use in regulation activity [15-17]. These indicators should be easy to calculate, interpret and understand. Most importantly, the initial data for their calculation should be available. Nitrogen surplus and NUE meet these requirements.

Many publications quote the results from the analysis of these indicators at different levels-country, individual region, different farms and different climatic zones [10,13,18-22]. The authors of [19] report on comparing the performance of around 1240 European farms, with the median NUE being 28\% for dairy farms and the $\mathrm{N}$ surplus being $156 \mathrm{~kg} \mathrm{~N} \mathrm{ha}^{-1}$. In recent years, there appeared to be much information on using NUE as a tool for policymakers to determine Nitrogen-Efficient Technologies and Management Practices [12,23,24]. However, many publications conclude that further research is needed to refine these indicators. The main reason is that they depend on many factors and decision-making on environmental mitigation requires an integrated approach. There is an understanding of the importance and correlation between these factors, yet the evidence is not enough to generalise and standardise these indicators [10-12,19,25].

This study aimed to identify the baselines for taking integrated manure management decisions with the use of N surplus and NUE towards reducing manure nitrogen losses and, consequently, environmental pressure. To achieve this aim, the environmental impacts associated with large-scale livestock farms in the Leningrad Region were defined by the selected methods. We analysed the spatial distribution of estimates by the administrative division of the territory and considered them at the levels of the region, municipal districts and particular farms. The study objective was to support the possibility of rational redistribution of manure nutrients between individual enterprises and between municipal districts for their more effective use. The outcomes are expected to be the starting point for establishing a centralised manure management system in the Leningrad Region designed for this purpose.

We estimated the role of systemic measures to improve NUE at farm level, with the relevant measures taking a due account for the interrelation between crop and livestock sectors. A specific aspect of this work was that the measures proposed to improve manure management at each assessment level (region, district or farm) were addressed to the corresponding policy-makers to support their decisions at a relevant level-from improving the performance of individual machines and technologies to establishing the nationwide system for nutrient load monitoring and control. The conducted research should improve the insight into the place and role of nitrogen balances in examining the nitrogen flows in livestock farming and inform developing approaches on a global scale. 
This study, as a case of North-West Russia and the Russian part of the Baltic Sea catchment area, will contribute to a better understanding of nitrogen flows and nitrogen use efficiency in this part of Europe within the framework of establishing the international nitrogen management system.

\section{Materials and Methods}

\subsection{Agricultural Sector in the Leningrad Region}

Data on agriculture by municipal districts and for the whole region concerning cropland area, farm animal stock by categories, animal and crop output and mineral fertilisers applied were taken from state agricultural statistics [26].

The Leningrad Region covers an area of 85.9 thousand $\mathrm{km}^{2}$ with a population of 1875.9 thousand people in 2018. The total agricultural land occupies 225,195 hectares, of which 209,853 hectares belong to agricultural organizations. The Leningrad Region is divided into 17 municipal districts. In the study, they are provisionally numbered from 1 to 17. Two districts (No. 1 and No. 13) were not considered in the study as they do not have agricultural enterprises on their territory and produce less than $0.1 \%$ of the total regional output on private household plots [27].

The Leningrad Region features an intensive agricultural production, with animal husbandry being the main branch. There are above 900 agricultural organizations and private farms in the region, including 142 large-scale agricultural enterprises: 94 cattle complexes or $66 \%$ of the total number, 8 pig complexes or $9 \%, 12$ poultry factories or $9 \%, 2$ mixed-type enterprises (cattle and pigs) or $1 \%$ and 26 crop growing enterprises or $12 \%$ of the total number. These enterprises house above 160 thousand head of cattle, 200 thousand head of pigs and 29 million head of poultry. This study considered statistical data on agricultural organisations accounting for above $90 \%$ of total agricultural output in the region.

More than $70 \%$ of cattle complexes in the Leningrad Region house above 1000 head at any one time; among them 42 complexes-from 1000 to 2000 head and 30 complexeshouse above 2000 head.

Above $65 \%$ of the total pig stock in the region (123,407 head) are found in one district (No. 17) on two pig complexes.

The total poultry stock in the Leningrad Region is 29 million head, with $61 \%$, or 18 million head, being housed in District No. 9.

A specific feature of livestock husbandry in the Leningrad Region is the feeds supplied from other parts of the country. Pig complexes and poultry factories operate on such feeds only. The main cultivated crops in the region are annual and perennial grasses, cereals and legumes used in cattle feed making.

A major part of agricultural land in the region has sod-podzolic automorphic soils. In general, however, more than half of agricultural land has soils with a different state of cultivation. At the same time, the hydrothermal coefficient exceeds 1.0, creating conditions for waterlogging of agricultural soils. Therefore, the effective use of organic fertilisers is needed to improve soil fertility. The infrastructure of water reclamation systems is also of importance in this respect [28].

\subsection{Indicators}

The results of nitrogen balance calculations for the region, municipal districts and individual farms by the methods from $[8,14,29]$ were used as indicators of the environmental impact of livestock husbandry. The nitrogen flows in this sector were considered as shown in Figure 1. 


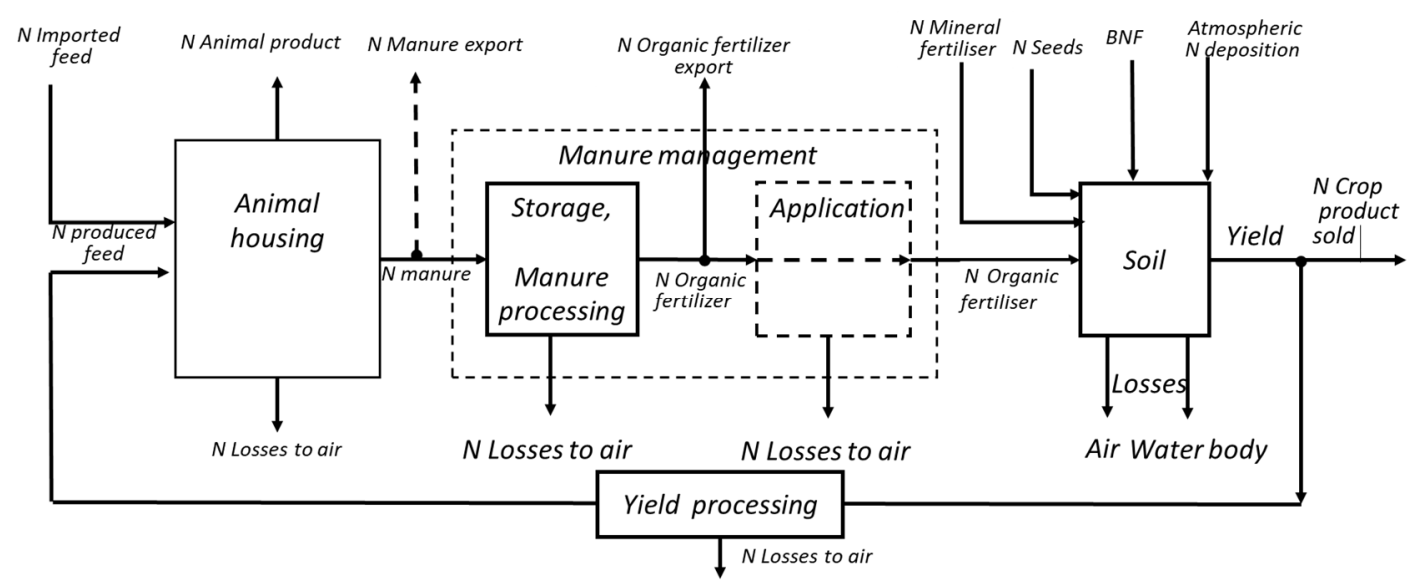

Figure 1. Nitrogen flows in livestock husbandry.

The following indicators were calculated:

- Livestock density index $\left(V_{h}\right)$ was calculated as

$$
V_{h}=\frac{H_{g}}{S_{p}}, \mathrm{LSU} \mathrm{ha}^{-1}
$$

where $H_{g}$ - the stock of animals converted in livestock units (LSUs) [30]; $S_{p}$-area of agricultural land on the territory under consideration, in ha.

- $\quad$ Nitrogen Use Efficiency (NUE) was calculated as

$$
\mathrm{NUE}=\frac{\sum N_{\text {output }}}{\sum N_{\text {input }}} \cdot 100 \%
$$

- Nitrogen surplus (Nsurplus) was calculated as

$$
N_{\text {surplus }}=\frac{\sum N_{\text {inputs }}-\sum N_{\text {outputs }}}{\text { area of agricultural land }}, \mathrm{kg} \mathrm{ha}^{-1} \mathrm{yr}^{-1}
$$

The inputs and outputs for calculating the nitrogen balance for various production chain components were defined as follows.

For the crop sector, a field N balance and NUEFIELD were calculated, with the inputs being the nitrogen in organic fertilisers, mineral fertilisers and seeds, and also nitrogen fixation and nitrogen deposition. The outputs here were the nitrogen in all crop products including feed for own needs.

For the livestock sector, a stable $\mathrm{N}$ balance and NUE inputs being the nitrogen in feed and bedding and the outputs being the nitrogen in milk, meat, eggs and pedigree animals for sale.

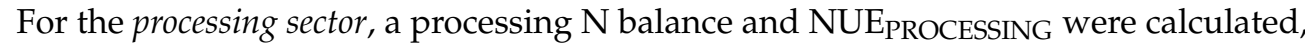
with the inputs being the nitrogen in the harvested crops and the outputs being the nitrogen in the on-farm produced forage (hay, silage) and concentrate feed.

The farm-gate $\mathrm{N}$ balance (FGB) was used to assess the whole production system, with the inputs being the nitrogen in feed, bedding, mineral fertilisers and seeds, as well as biological nitrogen fixation and nitrogen deposition. The outputs here were the nitrogen in the sold products-milk, meat, eggs, pedigree animals, crop products and manure.

When calculating a farm-gate $\mathrm{N}$ balance, the nutrient content in the crop and livestock products was determined by default data from [14,29]; biological nitrogen fixation and atmospheric nitrogen deposition were determined by Russian methodological recommendations [31]; manure output and nutrient content in animal and poultry excrement were 
determined following the Russian regulatory documents; and the average losses during manure processing into organic fertilisers were assumed to be $20 \%$ according to $[4,32]$.

The initial data for the farm-gate $\mathrm{N}$ balances were taken from the surveys of pilot farms as a part several projects from 2011 to 2018.

The NUE and N surplus at farm level were calculated by the farm-gate $\mathrm{N}$ balance. Field $\mathrm{N}$ balance was used for the environmental assessment of an agricultural enterprise, municipal district and region. The calculation methods from $[8,14,29]$ were applied.

Figure 2 shows the relationship of nitrogen flows in the $\mathrm{N}$ balances calculation. The presented diagram employs the idea and approaches proposed by $[13,14]$ for crop production. The diagram was used to assess the application range of different nutrient balances.

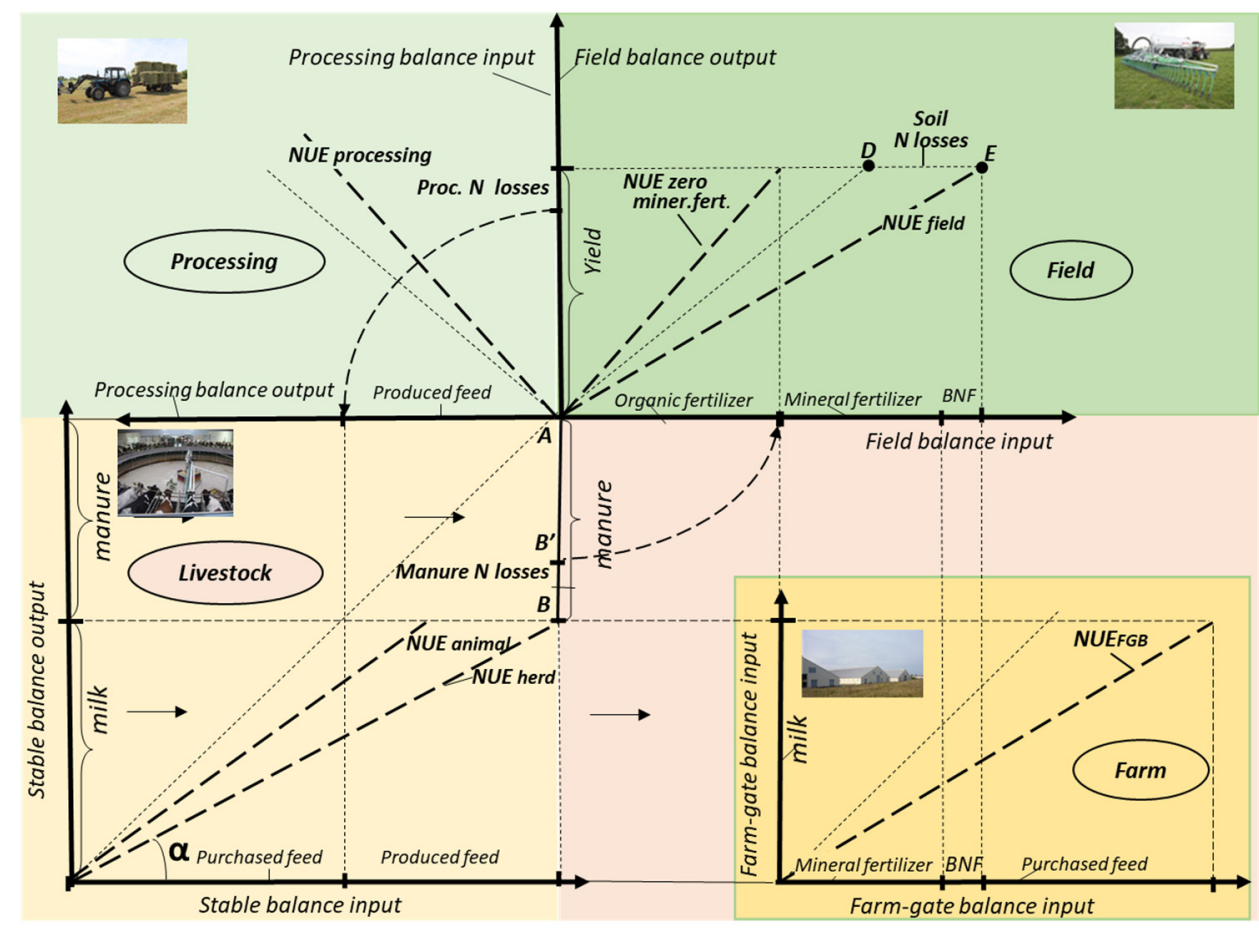

Figure 2. N input - N output diagram for a dairy farm.

Our study considered a mixed livestock-crop production system. The diagram considers a dairy farm for the case when all manure produced is applied to the own fields and all crop products are used for feed production only.

The diagram examines the nitrogen flows in the livestock and crop sectors as an integrated production system, which can be a farm, district or region. The nature of the relationship and the mutual influence of flows is the same at all levels. Only the scale and the corresponding management methods differ.

The diagram shows the components of inputs and outputs of balances for calculating NUE for the crop, processing and livestock sectors. All sectors are interrelated in the calculation of balances. The output of the field $\mathrm{N}$ balance (crop yield) is an input for a processing $\mathrm{N}$ balance. The output of a processing $\mathrm{N}$ balance (feed) is a part of the stable $\mathrm{N}$ balance input. The farm-gate $\mathrm{N}$ balance inputs overlap with the field $\mathrm{N}$ balance inputs, and the farm-gate $\mathrm{N}$ balance outputs coincide with those of the stable $\mathrm{N}$ balance.

The diagram can graphically estimate the measures to increase NUE and reduce losses in different sectors.

The diagram shows the nitrogen losses in the manure handling system and in the crop sector based on the idea that in the farm-gate $\mathrm{N}$ balance

$$
N \text { input }-N \text { output }=N \text { losses manure }+N \text { losses soil }
$$


In the livestock sector, the manure nitrogen is shown as the $A B$ segment on the diagram. The fields receive the organic fertiliser, that is, manure ready for application after processing and/or storage ( $\mathrm{AB}^{\prime}$ in the diagram). $\mathrm{BB}^{\prime}$ are the nitrogen losses in the manure handling system. They are known to include the losses to the atmosphere from the livestock houses and manure storages and during field application $[8,11]$. These losses are determined by a calculation method, with the uncertainty sometimes reaching $50 \%$. The overall nitrogen losses during manure processing into an organic fertiliser may be up to $20 \%[8,33]$.

The field losses to the environment are calculated as:

$$
N \text { losses soil }=N \text { losses air }+N \text { losses leaching }+N \text { soil stock }
$$

Graphically, in a very simplified way, the maximum possible reduction of $\mathrm{N}$ losses soil is shown by the DE segment on the diagram. Currently, these values are not reliably determined [34].

In principle, the proposed diagram shows the need for an integral approach and can become the starting point for optimising livestock production at different levels.

\section{Results}

\subsection{Manure Nitrogen Produced in Municipal Districts of the Leningrad Region}

The Leningrad Region produces yearly above 3 million tons of cattle manure, above 663 thousand tons of pig manure, and more than 1.3 million tons of poultry manure.

Manure-based organic fertilisers are the major source of nitrogen input to fields.

Table 1 presents the calculation data on the livestock density per unit of agricultural land and nitrogen content in organic fertilisers ready for field application in the municipal districts under consideration. The manure output was calculated only from the animal and poultry stock in agricultural enterprises; personal subsidiary plots were ignored due to their insignificant contribution.

Table 1. Livestock units and organic fertiliser nitrogen per hectare in the municipal districts of the Leningrad Region (as of the end of 2016).

\begin{tabular}{|c|c|c|c|c|c|}
\hline \multirow{2}{*}{$\begin{array}{l}\text { Municipal Districts in } \\
\text { the Leningrad Region }\end{array}$} & \multirow{2}{*}{ LSU ha ${ }^{-1}$} & \multirow{2}{*}{$\begin{array}{c}\text { Nitrogen in Organic Fertilisers } \\
\text { Ready for Field Application, } \\
\mathrm{kg} \mathrm{ha}^{-1}\end{array}$} & \multicolumn{3}{|c|}{ Animal Stock, Head } \\
\hline & & & Cattle & Pigs & Poultry \\
\hline District No. 2 & 0.5 & 69.5 & 23,700 & 1128 & 2000 \\
\hline District No. 3 & 0.8 & 90.0 & 11,769 & 5850 & 3500 \\
\hline District No. 4 & 1.1 & 118.1 & 10,222 & 6743 & 4200 \\
\hline District No. 5 & 6.9 & 358.0 & 10,680 & 2243 & $6,000,000(2) *$ \\
\hline District No. 6 & 1.5 & 90.0 & 17,181 & 8742 & $2,950,000$ \\
\hline District No. 7 & 0.3 & 37.5 & 6897 & 226 & 3950 \\
\hline District No. 8 & 0.5 & 49.6 & 5075 & 108 & 2870 \\
\hline District No. 9 & 67.4 & 2025.4 & 1000 & 367 & $18,000,000(2) *$ \\
\hline District No. 10 & 1.4 & 46.2 & 1400 & 6369 & 1780 \\
\hline District No. 11 & 2.6 & 156.6 & 8609 & 6424 & $2,400,000(2)$ * \\
\hline District No. 12 & 1.0 & 90.8 & 22,701 & 18,680 & 7800 \\
\hline District No. 14 & 1.4 & 128.7 & 21,964 & 20,253 & 2780 \\
\hline District No. 15 & 0.5 & 64.0 & 5067 & 20 & 4980 \\
\hline District No. 16 & 0.7 & 77.8 & 5000 & 357 & 5890 \\
\hline District No. 17 & 3.3 & 125.2 & 13,348 & $123,407(2)$ * & 10,000 \\
\hline
\end{tabular}

* in parenthesis-the number of large-scale agricultural enterprises.

From Table 1, four districts in the Leningrad Region exceed the density of $1.5 \mathrm{LSU}_{\mathrm{ha}}{ }^{-1}$ adopted in the Baltic Sea countries [7] due to the substantial poultry and pig stock found in these areas. Historically, most poultry factories and pig complexes do not have enough fields to apply all the manure they produce as an organic fertiliser. These enterprises are supplied mainly with purchased feed; they are not interested in producing their own more 
expensive feed. Therefore, organic waste disposal is a much more acute issue for these enterprises than the cattle farms.

It should be noted that this circumstance is not critical if a well-planned system of manure processing and organic fertiliser application or sale is in place.

\subsection{Field N Balance of Municipal Districts and the Leningrad Region}

The field $\mathrm{N}$ balance was calculated for the municipal districts under consideration and the whole region following the accepted methodology to assess NUE of all manure nitrogen produced on all livestock and poultry enterprises in the Leningrad Region. The results are shown in Figure 3 and in Tables 2 and 3.
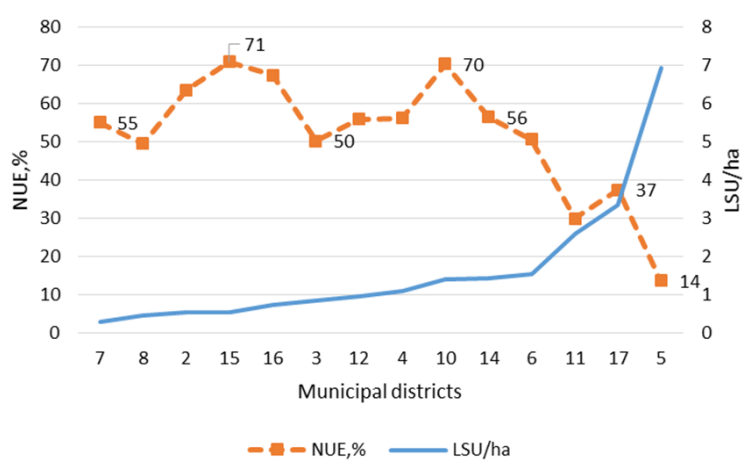

(a)

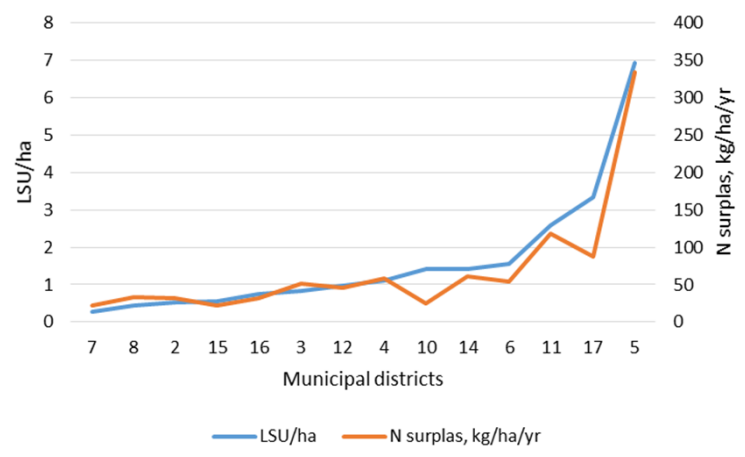

(b)

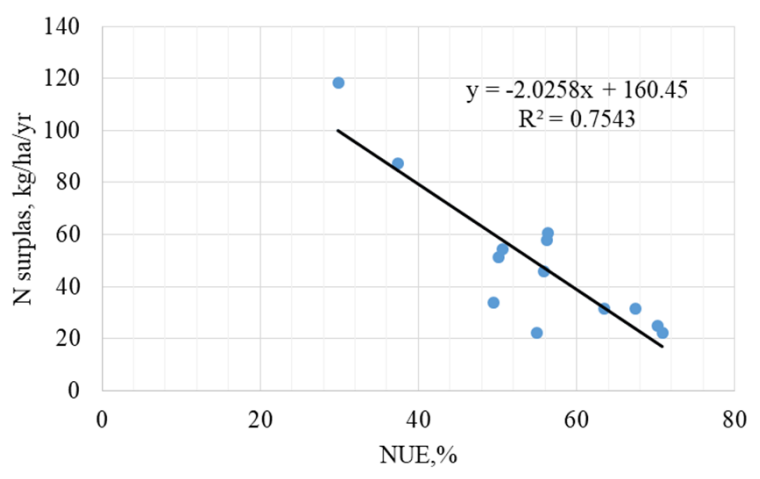

(c)

Figure 3. Calculation results of field N balances of the municipal districts: (a) NUE and livestock density per hectare of municipal districts; (b) $\mathrm{N}$ surplus and livestock density per hectare of municipal districts; (c) NUE and N surplus (The graphs do not show District No.9 with N surplus of $3082 \mathrm{~kg} \mathrm{~N} \mathrm{ha}^{-1} \mathrm{yr}^{-1}$ and animal density of $67.4 \mathrm{LSU} \mathrm{ha}^{-1}$ ). 
The uneven distribution of livestock enterprises across the region resulted in a wide range of environmental estimates by districts.

Therefore, the solutions to improve the manure management for the region under consideration are to be searched separately for two groups of districts following the spatial distribution of indicators and the identification of "hot spots" [35].

The distribution of indicators by districts shown in Figure 3 was the basis for identifying a group of 11 districts with the animal density below three LSU ha ${ }^{-1}$ for further consideration. Table 2 shows the descriptive statistics for this group of "environmentally friendly" districts. Districts No. 5,9,11 and 17 are further considered as "hot spots".

Table 2. Descriptive statistics for calculated indicators of 11 "environmentally friendly" districts.

\begin{tabular}{|c|c|c|c|c|c|}
\hline & Mean & Median & Min & $\operatorname{Max}$ & $\begin{array}{c}\text { Standard } \\
\text { Deviation }\end{array}$ \\
\hline $\mathrm{LSU} \mathrm{ha}^{-1}$ & 0.89 & 0.83 & 0.28 & 1.55 & 0.43 \\
\hline NUE, $\%$ & 59 & 56 & 49 & 71 & 8 \\
\hline $\mathrm{N}$ surplus, $\mathrm{kg} \mathrm{N} \mathrm{ha}^{-1} \mathrm{yr}^{-1}$ & 39.63 & 33.63 & 22.20 & 60.75 & 14.70 \\
\hline
\end{tabular}

Table 3. Field $\mathrm{N}$ balance for the whole Leningrad Region.

\begin{tabular}{ccc}
\hline & Nitrogen Input, Output Items & $\mathbf{N ~ t}$ \\
\hline \multirow{2}{*}{ INPUTS } & Seeds & 246.34 \\
& Organic fertilisers produced in the & $29,066.7$ \\
& Leningrad Region & 1771.2 \\
& Mineral fertilisers & 1049.27 \\
& Atmospheric nitrogen deposition & 1049.27 \\
& Biological nitrogen fixation & $\mathbf{3 3 , 1 8 2 . 7}$ \\
\hline Total INPUT, t N & 2097.5 \\
& Grain & 427.86 \\
& Potato & 8641.58 \\
& Hay & 210.82 \\
& Silage & $\mathbf{1 1 , 3 7 7 . 8}$ \\
\hline Calculation result & Total OUTPUT, t N & $\mathbf{2 1 , 8 0 5}$ \\
& Input-output, t N & $\mathbf{3 4}$ \\
& NUE, $\%$ & $\mathbf{1 0 3}$ \\
\hline
\end{tabular}

\subsection{Nitrogen Balances at Farm Level}

\subsubsection{Balances for a Dairy Farm}

The farm-gate $\mathrm{N}$ balance was calculated for a dairy farm located in the municipal district No. 12. The initial data for 2011, 2012 and 2016 were used. Field N balance was also calculated for 2016. That year, the farm housed 1633 head of cattle, including 833 cows; the agricultural area was 2715 ha.

Over the past five years, the farm has reorganized its production system. The agricultural land area remained the same; the number of cows increased by 33 head. By 2016, the farm switched to another cattle feeding system and replaced the black-and-white cows with the Holstein ones. As a result, the average milk yields increased from $7590 \mathrm{~kg} \mathrm{cow}^{-1} \mathrm{yr}^{-1}$ to $9000 \mathrm{~kg} \mathrm{cow}^{-1} \mathrm{yr}^{-1}$. The share of grain in the cropping system increased while the amount of purchased compound feed reduced. In 2012, 190 tons of mineral fertilisers were applied to the fields; in 2016, mineral fertilisers were not applied at all. As a result, NUEFGB increased from 21 to $60 \%$ and $\mathrm{N}$ surplus decreased from $57 \mathrm{~kg} \mathrm{ha}^{-1}$ to $12 \mathrm{~kg} \mathrm{ha}^{-1}$.

The calculated balances are presented in Table 4 and Figure 4. 
Table 4. Farm-gate $\mathrm{N}$ balance ufield $\mathrm{N}$ balance for a dairy farm.

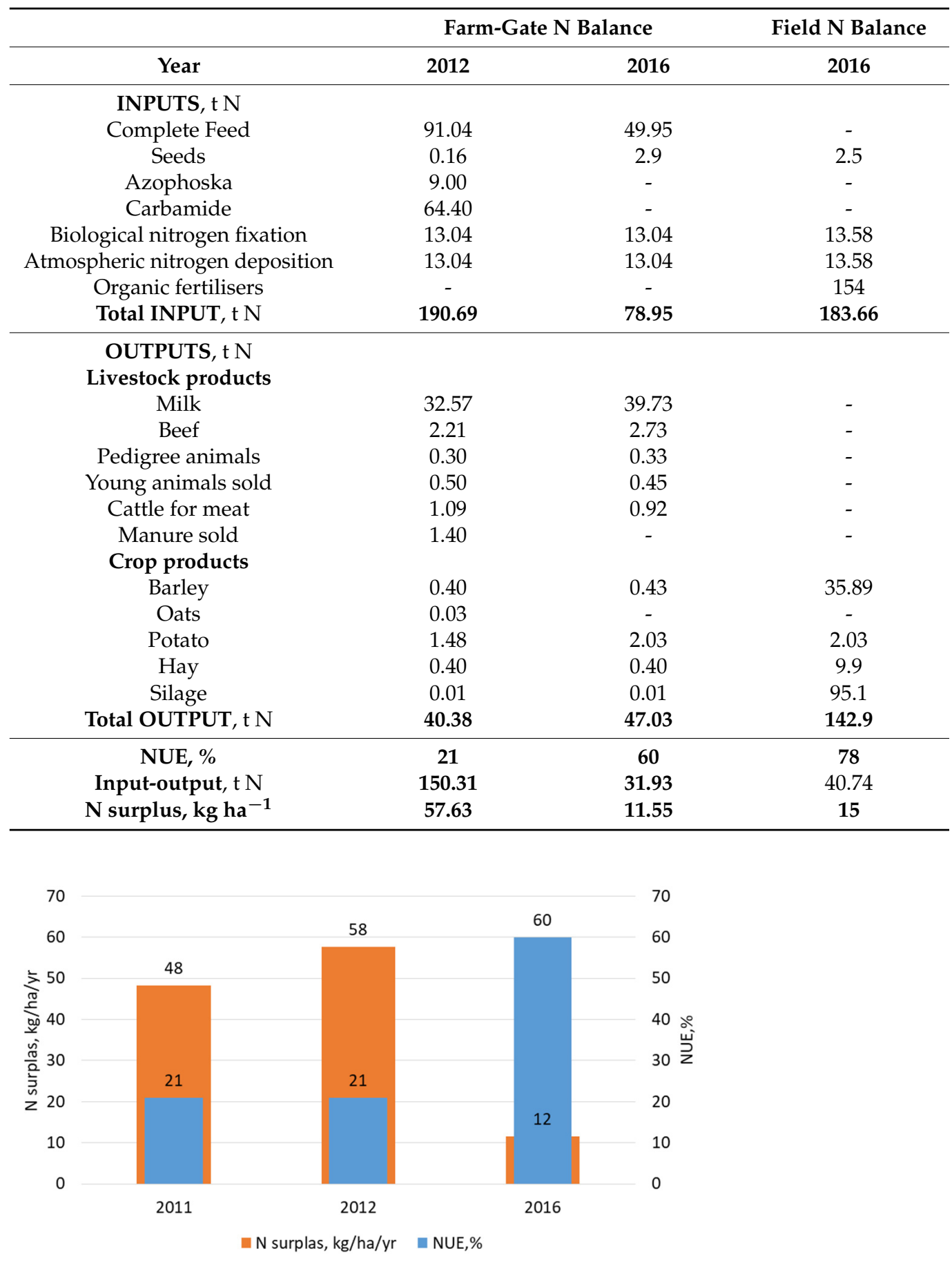

Figure 4. NUE иN surplus from the farm-gate N balance of a dairy farm in 2011, 2012 and 2016.

The high NUE value of $78 \%$ from the field $\mathrm{N}$ balance is of concern [13]. Under the existing crop-growing system, insufficient nutrients may cause land degradation. This calculation result allows the conclusion that the farm fields have the potential to receive additional nitrogen with organic or mineral fertilisers to maintain and improve soil fertility. 


\subsubsection{Farm-Gate $\mathrm{N}$ Balance for a Poultry Factory}

The farm-gate $\mathrm{N}$ balance was calculated for an egg poultry factory typical for the Leningrad Region with an overall population of 1,100,000 head, including young poultry and 850,000 laying hens. The agricultural land area is $545 \mathrm{ha}$, where cereals are grown for sale. The average egg-laying rate per hen is 329 pieces per year and the average productive period of hens is 460 days.

The inputs in the farm-gate $\mathrm{N}$ balance were purchased feed and grain seeds; the outputs were eggs, poultry meat, manure-based organic fertilisers and feed grain. The manure produced had $121.6 \mathrm{~N} \mathrm{t}$, taking into account the losses at the manure processing stage, but only $65.4 \mathrm{t} \mathrm{N}$ were used on the own fields (Table 5).

Table 5. Farm-gate balance for a poultry factory.

\begin{tabular}{ccc}
\hline & Nitrogen Input, Output Items & $\mathbf{N ~ t}$ \\
\hline & Feed & 1156.9 \\
\multirow{2}{*}{ INPUTS } & Seeds & 1.67 \\
& Atmospheric nitrogen deposition & 2.73 \\
& Biological nitrogen fixation & 2.73 \\
& Total INPUT, t N & $\mathbf{1 1 6 4 . 0 2}$ \\
\hline OUTPUTS & Eggs & 345.65 \\
& Poultry meat & 13.77 \\
& Crop products (grain) & 39.2 \\
& Organic fertilisers & 56.2 \\
Calculation result & Total OUTPUT, t N & 454.86 \\
& Input-output, $\mathrm{t} \mathrm{N}$ & $\mathbf{7 0 9 . 1 6}$ \\
& NUE, $\%$ & $\mathbf{3 9}$ \\
& $\mathbf{N}$ surplus, $\mathbf{~ k g ~ h a - 1}$ & $\mathbf{1 3 0 1}$ \\
\hline
\end{tabular}

The farm-gate $\mathrm{N}$ balance of the poultry factory shows the $\mathrm{N}$ surplus that needs to be redistributed between other farms.

\section{Discussion}

\subsection{Assessment of Nitrogen Flows by the N Balance Calculation at the Regional Level}

The available initial data allowed calculating the field $\mathrm{N}$ balance for the whole region (Table 3). The farm-gate balance for the region and its municipal districts is difficult to calculate due to the lack of reliable data on the export and import of products since the region features extensive business links between its districts.

The main input in region level balance is nitrogen in organic fertilisers (processed manure) $-138.5 \mathrm{~kg} \mathrm{~N} \mathrm{ha}^{-1}$, or $87 \%$. The share of mineral fertilisers is only $12 \%$. In the Baltic Sea countries, this share varies from 42 to $62 \%$ [36]. Therefore, the measures to improve NUE are related mainly to the manure management system. The output in the $\mathrm{N}$ balance is the nitrogen in crop products for animal feeding.

It is difficult to assess the obtained NUE and N surplus, since they depend on many factors, and it is fundamentally impossible to establish the norms. These indicators show a wide scale dispersion by country [10,13,18-22,37]. According to [36], in the Baltic Sea countries the Gross Nitrogen Surplus (GNS), an Eurostat/OECD indicator, ranges from 24 to $82 \mathrm{~kg} \mathrm{~N} \mathrm{ha}^{-1}$ and NUE FIELD is in the range from 66 to $86 \%$.

Therefore, the calculated indicators were roughly compared with the data shown in Figures 16 and 17 from [13]. An NUE interpreted as "balanced fertilisation", and an N surplus field of $103 \mathrm{~kg} \mathrm{~N} \mathrm{ha}^{-1}$ can be considered as "modest". 
Losses to the environment ( $\mathrm{N}$ input $-\mathrm{N}$ output) are 21,805 $\mathrm{t} \mathrm{N} \mathrm{yr}^{-1}$. According to our calculations included in [36], the air emissions of $\mathrm{NH}_{3}, \mathrm{~N}_{2} \mathrm{O}$, and $\mathrm{NO}$ in the Leningrad Region in 2016 amounted to 12,028 t N yr [36]. Thus, following the formula (4), the losses through soil into the water bodies were $9777 \mathrm{t} \mathrm{N} \mathrm{yr}^{-1}$. These data correspond to [34]. From here, the possible volume of emission reduction by the use of relevant machines and equipment on large-scale agricultural enterprises was determined. If emissions are reduced by at least $20 \%$, then the nitrogen saving in organic fertilisers will be commensurate with the amount of mineral fertilisers currently applied in the region.

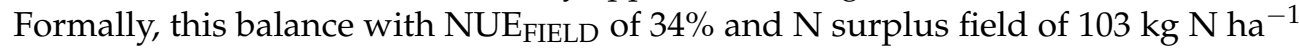
may not require any actions in the region. On the other hand, it indicates the possibility of the redirection of nitrogen flows within the region to address the "hot spots" challenge.

\subsection{NUE and N Surplus in the Municipal Districts}

Performance indicators NUE and N surplus from the field $\mathrm{N}$ balance for the municipal districts under consideration (except District No. 9) are shown in Figure 3 in the Results section.

The authors of [37] assume that 'regions with $2 \mathrm{LSU}^{-1} \mathrm{~h}^{-1}$ face environmental problems related to animal manure management; regions with $4 \mathrm{LSU}^{-1}$ in addition meet societal objections'. The recommended livestock density for the Baltic Sea countries according to [7] is $1.5 \mathrm{LSU} \mathrm{ha}^{-1}$. Only 11 municipal districts with a livestock density index below 1.55 meet this requirement. They were included in the first group of "environmentally friendly" districts.

In Districts No. 5 and No. 9, the livestock density is by an order greater-7 and 67.9 $\mathrm{LSU} \mathrm{ha}^{-1}$, respectively. These districts may be considered "hot spots" in the region by environmental indicators. They accommodate the major poultry stock on the largest poultry factories with practically no agricultural land. These districts are included in the second group. At the same time, the agricultural enterprises located in these districts are highly advanced in terms of technological, economic, and performance parameters indexes.

\subsection{NUE and N Surplus for "Environmentally Friendly" Municipal Districts}

Eleven districts were included in the group for consideration. These districts feature mainly dairy farming, accommodating $80 \%$ of cows, $34 \%$ of pigs and only $10 \%$ of the poultry of the total animal stock of the region. Figure 5 shows the relationship of NUE (\%), and $\mathrm{N}$ surplus $\left(\mathrm{kg} \mathrm{ha}^{-1}\right)$, with $\mathrm{N}$ input $\left(\mathrm{kg} \mathrm{ha}^{-1}\right)$ in these districts.

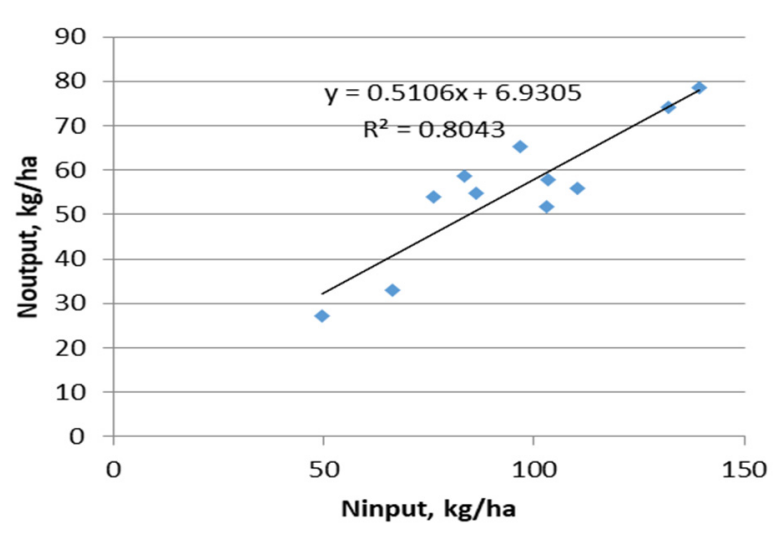

(a)

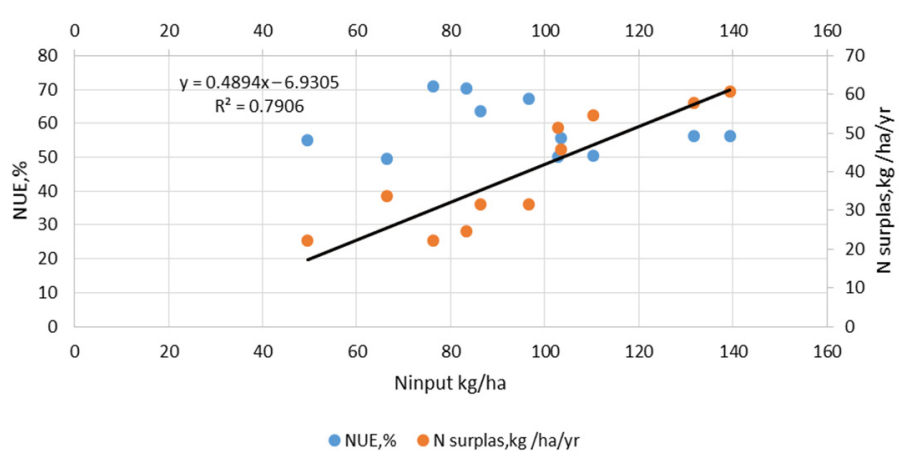

(b)

Figure 5. Indicators from the field N balance calculation for "environmentally friendly" districts: (a) N input and N output, $\left(\mathrm{kg} \mathrm{ha}^{-1}\right)$; (b) NUE (\%) and $\mathrm{N}$ input $\left(\mathrm{kg} \mathrm{ha}^{-1}\right)$. 
The linear relationship between the parameters (with $\mathrm{R}^{2}=0.8$ ) in Figure 5 is in line with the literature data [19]: $N$ output and, accordingly, $N$ surplus increase with an increase in $\mathrm{N}$ input flows.

NUE and N surplus from the field $\mathrm{N}$ balance for the group of "environmentally friendly" districts are satisfactory according to the "Tentative scheme for the interpretation of N surplus values" from [13]. They indicate the possibility of intensifying the production by increasing the dose of applied fertilisers, organic ones included. Currently, the applied mineral fertilisers vary from 2 to $13 \mathrm{~kg} \mathrm{~N} \mathrm{ha}^{-1}$ that is significantly less than used in European countries [19,36].

Many farms in the region have the following common problems:

- Imperfect and/or low-level crop growing practices under which the crops do not reach their biological potential and demonstrate low yields; and

- $\quad$ Big nutrient losses during manure processing, storage and field application under poor organic fertiliser nutrients accounting.

Properly addressing these problems should improve the efficiency of resource use.

\subsection{Improving Nitrogen Efficiency at Farm Level}

The data on the whole region and separate municipal districts allows for a conceptual assessment of the possible ways to enhance production efficiency. However, the measures for improving the environmental performance of a particular farm are chosen by many factors reflecting the relationship between the crop and livestock sectors on this farm.

Measures to improve NUE through organizational activity and improved practices can be visualized using the diagram in Figure 2.

In the diagram, the NUESTABLE in the livestock sector graphically increases with an increase of the $\alpha$ angle in the feed-milk triangle. The following available organizational measures contribute to higher milk yields and lower manure nitrogen:

- $\quad$ improving animal breeds and feed conversion ratio [38]

- low-protein diets [8]

- $\quad$ increasing the share of dairy cows in the total herd since NUE animal > NUE herd, and

- $\quad$ reducing the number of replacement animals through better housing conditions and higher number of calvings [38].

Increasing NUE and decreasing $\mathrm{N}$ surplus in the crop sector are conditioned by soil properties, cultivated crops and crop management practices.

The processing sector is intermediate between the field and the animals; it converts crop products into feed. Higher NUE processing reduces the share of purchased feed. NUE processing is increased by minimising the nutrient losses, which may reach appr. $20 \%$ [39] and is governed by the harvesting and processing techniques in this sector. The sector's effectiveness depends on the operational pattern adopted: sometimes the grain produced on the farm is transferred to the feed mill for processing and then returns to the farm as a complete feed. This case generates additional nitrogen losses and additional air pollution associated with transportation.

The grazing system partially excludes the losses in the processing sector. No grazing, as is customary in most farms in the Leningrad Region, theoretically reduces NUE processing.

The farm-gate $\mathrm{N}$ balance is the resulting tool to reflect the changes in each sector. It does not consider internal links but serves for a comprehensive assessment of change outcomes in separate elements of the object under study. The analysis of balance components demonstrates that under constant characteristics of crop and livestock production NUE $E_{F G B}$ may be improved by reducing the purchased feed and fertilisers. This is possible through enhancing the own feed production by changing the composition of cultivated crops or intensifying the processes.

In addition to the above organisational measures for improving NUE, the methods of direct reduction of nitrogen losses to the environment by using relevant machines and equipment are of great importance. 
An ideal scenario of decision-making on NUE improvement through the introduction of promising technologies [40] should consider all elements of the technological chain including the manure handling system-animal houses, storages and field application. Target-oriented measures should be selected for each element $[3,8,41]$.

Further, the application of nitrogen balances for environmental assessment is considered in the example of farms in the Leningrad Region.

Table 6 compares the farm-gate $\mathrm{N}$ balance and field $\mathrm{N}$ balance indicators for the considered dairy farm and poultry factory with the same indicators calculated for the municipal districts, where these enterprises are located, and for the whole region.

Table 6. NUE иN surplus for the dairy farm and poultry factory, relevant municipal districts and the whole region.

\begin{tabular}{|c|c|c|c|}
\hline & LSU ha ${ }^{-1}$ & NUE, $\%$ & N Surplus, $\mathrm{kg} \mathrm{ha}^{-1}$ \\
\hline Region, field $\mathrm{N}$ balance & 2.36 & 34 & 103 \\
\hline District No. 6, field N balance & 1.55 & 51 & 54.55 \\
\hline Poultry factory, farm-gate $\mathrm{N}$ balance & 15.6 & 39 & 1301 \\
\hline District No. 12, field N balance & 0.96 & 56 & 45.9 \\
\hline Dairy farm, 2016, field N balance & 0.40 & 78 & 15 \\
\hline Dairy farm, 2016, farm-gate $\mathrm{N}$ balance & 0.40 & 60 & 11.55 \\
\hline Dairy farm, 2012, farm-gate $\mathrm{N}$ balance & 0.37 & 21 & 57.6 \\
\hline
\end{tabular}

From Table 6, an $\mathrm{NUE}_{\mathrm{FGB}}$ of $60 \%$ for a dairy farm in 2016 was close to the average for the district. Compared to 2011, NUE $_{\mathrm{FGB}}$ increased owing to no mineral fertilisers being applied, a lower share of purchased compound feed in the diets and a simultaneous increase in animal productivity. The low $\mathrm{N}$ surplus against the regional average shows the possibility of increasing the number of animals on the farm and the field application of organic fertilisers imported from other districts of the region. When discussing the prospects of this farm, the NUE field of $78 \%$ needs focusing attention. Its further increase may lead to soil depletion. Maintaining phosphorus balance is also of importance.

The lower amount of applied mineral fertilisers can be achieved through the use of technologies that contribute to reducing the nitrogen losses from manure. Such a scenario for the 2011 baseline data for the same farm is discussed in [42] which "demonstrates the assessment results of the effectiveness of the farm introduction of BAT for manure processing and application-covering of compost heaps and immediate ploughing of organic fertilisers after spreading. The calculated values of total nitrogen losses are reduced by $20 \%$; the saving of mineral fertilisers owing to higher nitrogen content in applied organic fertilisers can be $18 \mathrm{t} \mathrm{yr}^{-1 "}$.

The farm-gate $\mathrm{N}$ balance for a poultry factory located in an "environmentally friendly" district (see Table 6) with a high $\mathrm{N}$ surplus shows that the solution to the manure problem lies in its export from the farm territory. The manure may be also processed by the on-site bio-fermentation in chamber-type fermenters to reduce traffic volumes [3].

Under the conditions of the Russian Federation, the use of aggregated indicators of the farm-gate $\mathrm{N}$ balance for environmental assessment at farm level may become relevant for agricultural producers in the context of tightening environmental legislation and the introduction of the BAT system [3]. Currently, in this country, the nutrient balance is calculated in regular agronomic practice when determining the fertilisation doses for each field depending on the crop, soil and target yield [31]. NUE seems to be the most understandable indicator for agricultural producers compared to other environmental indicators. Emissions and discharges are either calculated or determined by complex and expensive measurements. NUE is advisable to be viewed in a dynamic sense when assessing the effectiveness of environmental measures, for example, at the request of supervisory environmental authorities. 


\subsection{Municipal Districts with High Livestock Density ("Hot Spots")}

The inevitable environmental problems at agricultural enterprises located in Districts No. 5, 9, 11 and 17 ("hot spots") with livestock density from 2.6 to $67 \mathrm{LSU} \mathrm{ha}^{-1}$ (see Table 7) can be solved only at the regional level. Districts No. 5 and No. 9 are found in the most difficult situation. The only solution seems to be the export of manure nitrogen outside of these districts. The indicators for the region prove that it can make use of this resource.

At present, the poultry factories distribute the manure through their own effort. Unfortunately, there is no reliable data on where and how much manure is exported.

Table 7 shows the general possibilities of the scenario for redistribution of organic fertilisers from the "hot spots" - municipal districts No. 5, 9 and 11, to the "environmentally friendly" ones, allowing each district to increase the $\mathrm{N}$ surplus to the values averaged over the region. Obviously, NUE in "environmentally friendly districts" will decrease in this case. A possible crop yield increment is difficult to assess. However, even if crop productivity remains the same, the soil state will improve. In principle, under such a redistribution, some farms may stop using mineral fertilisers. On the other hand, NUE and $\mathrm{N}$ surplus by districts can be used to assess the adopted logistic redistribution scheme from an environmental standpoint.

A similar calculation pattern may be applied to the redistribution of fertilisers between the particular farms within a district. To introduce such a system is a not an easy task, which requires the collaboration of logistic, energy, economic, and managerial sectors. The proposed approach is the initial stage of work. Currently, as a first step, an interactive programme is under development for agro-monitoring and nutrient load management in the Russian part of the Baltic Sea catchment area within the borders of the Leningrad Region [43].

A promising direction in the manure management is its multi-stage processing. Membrane-based nitrogen recovery from pig manure is of interest in this respect, with the prospecting results presented in [44]. Creating a collective integrated treatment system for energy recovery and nutrient removal from livestock manure in Northern Italy $[45,46]$ is also an interesting experience. In this case, the economic aspects come to the fore along with environmental issues $[3,46]$. The cost of measures associated with environmentally friendly use of produced manure on the farms without their own agricultural land is comparable to the cost of the main production.

Table 7. Maximum amount of nitrogen that can be supplied to the districts with $\mathrm{N}$ surplus $<103 \mathrm{~kg} \mathrm{ha}^{-1}$.

\begin{tabular}{|c|c|c|c|c|}
\hline \multirow{2}{*}{$\begin{array}{l}\text { Municipal } \\
\text { Districts }\end{array}$} & \multicolumn{3}{|c|}{ Calculated Indicators of Field N Balances } & \multirow{2}{*}{$\begin{array}{c}\text { Potentially Imported } \\
(+) \text { or Exported }(-) \\
\text { Nitrogen, } t\end{array}$} \\
\hline & NUE & $\begin{array}{l}\text { N Surplus, } \\
\text { kg ha }^{-1}\end{array}$ & $\begin{array}{l}\text { N (Input - } \\
\text { Output), t }\end{array}$ & \\
\hline District 2 & 64 & 31.52 & 1015.01 & +2309.11 \\
\hline District 3 & 50 & 51.27 & 661.34 & +712.14 \\
\hline District 4 & 56 & 57.72 & 556.47 & +254.01 \\
\hline District 5 & 14 & 333.90 & 3315.26 & -2267.72 \\
\hline District 6 & 51 & 54.55 & 1596.66 & +1397.33 \\
\hline District 7 & 55 & 22.33 & 414.99 & +2016.63 \\
\hline District 8 & 49 & 33.63 & 271.91 & +740.63 \\
\hline District 9 & 1 & 3082.51 & 8291.96 & -8087.05 \\
\hline District 10 & 70 & 24.76 & 65.04 & +196.57 \\
\hline District 11 & 30 & 118.52 & 1522.94 & -138.87 \\
\hline District 12 & 56 & 45.69 & 1128.37 & +1351.07 \\
\hline District 14 & 56 & 60.75 & 1019.20 & +315.10 \\
\hline District 15 & 71 & 22.20 & 150.85 & +556.72 \\
\hline District 16 & 67 & 31.54 & 159.08 & +309.81 \\
\hline District 17 & 37 & 87.15 & 1548.34 & +334.51 \\
\hline $\begin{array}{c}\text { Leningrad } \\
\text { Region }\end{array}$ & 34 & 103 & 21,805 & \\
\hline
\end{tabular}


Establishing a centre for the multi-stage processing of manure in the Leningrad Region needs a further feasibility study. One of the aims is to obtain new products, concentrated organic fertilisers in particular, to increase their economically feasible long transportation distance, including the delivery to other regions.

The situation in municipal districts No. 5 and No. 9 may be explained by a serious violation of current construction standards. The introduction of the BAT system in the Russian Federation provides for a stricter environmental impact assessment at the designing stage of large-scale agricultural enterprises to be constructed. The $\mathrm{N}$ balances, NUE and $\mathrm{N}$ surplus can be effectively used to substantiate the location of facilities to be built on the territory.

\section{Conclusions}

Arranging efficient manure management is the major environmental challenge in livestock farming in the Leningrad Region, with manure nitrogen being regarded as the main pollution source. The effect of large-scale livestock enterprises on the environment was assessed by nitrogen balances showing ways to reduce nitrogen losses. Nitrogen use efficiency and $\mathrm{N}$ surplus were calculated for the whole region and 15 municipal districts, with the source data taken from the state agricultural statistics.

The indicators at the regional level can be estimated as satisfactory-NUE $34 \%$ and N surplus $103 \mathrm{~kg} \mathrm{ha}^{-1}$ under the livestock density of $2.4 \mathrm{LSU} \mathrm{ha}^{-1}$. However, these indicators differ significantly by municipal districts. Eleven districts, where most dairy farms are located, may be considered as "environmentally friendly" with the mean NUE of 59 (SD 8) $\%$, mean $\mathrm{N}$ surplus of 39.6 (SD 14.7) $\mathrm{kg} \mathrm{ha}^{-1}$ and mean livestock density of 0.89 (SD 0.43 ) LSU ha ${ }^{-1}$. Four districts with large-scale pig complexes and poultry factories without sufficient agricultural land for manure application are identified as "hot spots", with the livestock densities ranging from 2.6 to $67 \mathrm{LSU} \mathrm{ha}^{-1}$, NUE ranging from 1 to $37 \%$ and $\mathrm{N}$ surplus in the range from 87 to $3082 \mathrm{~kg} \mathrm{ha}^{-1}$. The only relevant solution seems to be the export of manure nitrogen outside these districts. The regional indicators prove that the region can make use of it.

A scenario is suggested for the redistribution of organic fertilisers between the "hot spots" and the "environmentally friendly" districts, allowing each district to increase the N surplus to the values averaged over the region. A similar approach is recommended for application in the case of the redistribution of fertilisers between the particular farms within a district. The proposed approach is the initial stage of work. The option of creating the centres for multi-stage processing of manure to obtain new products, concentrated organic fertilisers in particular, to increase their economically viable transportation distance is also considered. Introducing such a system is not an easy task as it requires the collaboration of the logistic, energy, economic and managerial sectors.

Measures to improve the NUE of a particular farm through organisational activity and advanced practices are considered with the help of the " $\mathrm{N}$ input $-\mathrm{N}$ output" diagram plotted for a dairy farm. This diagram shows the principal need for an integral approach; it can become the starting point for developing a simple, user-friendly tool to search for ways to improve nitrogen use efficiency in livestock husbandry at different levels.

The proposed schematic diagram and the considered example of nitrogen flows on pilot farms illustrate the essential role of systemic measures for NUE improvement like increasing their own feed production and animal productivity and reducing mineral fertilisation and the role of low-emission manure handling practices.

According to the study outcomes, the comprehensive assessment of NUE at farm level requires both the farm-gate $\mathrm{N}$ balance and the field $\mathrm{N}$ balance for clearer insight into the soil impact. Under the conditions of Russia, the use of aggregated indicators of the farm-gate $\mathrm{N}$ balance for environmental assessment at farm level may become relevant for agricultural producers in the context of tightening environmental legislation and the BAT system introduction. NUE monitoring is advisable when assessing the effectiveness of mitigation measures, for example, at the request of supervisory environmental authorities. 
The performed study should improve the vision of the place and role of nitrogen balances in examining the nitrogen flows in livestock farming and inform developing approaches on a global scale.

Author Contributions: Conceptualization, A.B. and E.V.; methodology, N.K. and E.V.; validation, A.B., E.S. and N.K.; formal analysis, E.V.; investigation, E.V.; resources, A.B.; data curation, E.V., N.K. and E.S.; writing—original draft preparation, E.V., N.K.; writing—review and editing, A.B., E.V., N.K. and E.S.; visualization, E.V., E.S.; supervision, A.B., E.V.; project administration, A.B. and E.V.; funding acquisition, A.B. All authors have read and agreed to the published version of the manuscript.

Funding: The funding was provided by the Institute for Engineering and Environmental Problems in Agricultural Production (IEEP) — branch of Federal State Budgetary Scientific Institution "Federal Scientific Agroengineering Center VIM", Saint Petersburg, the Russian Federation.

Institutional Review Board Statement: Not applicable.

Informed Consent Statement: Not applicable.

Data Availability Statement: Generated data is publicly available and handled as stated in the Data Availability Statements in section "MDPI Research Data Policies" at https:/ /www.mdpi.com/ethics (accessed on 10 April 2021).

Acknowledgments: This paper has been developed under the UNECE Task Force on Reactive Nitrogen. It contributes to the INMS project "International Nitrogen Management System".

Conflicts of Interest: The authors declare no conflict of interest.

\section{References}

1. Russia in Figures, 2017. Statistical Handbook; Federal State Statistics Service: Moscow, Russia, 2017; p. 465. Available online: http:/ / www.gks.ru/free_doc/doc_2017/rusfig/rus17e.pdf (accessed on 13 February 2021). (In Russian)

2. Briukhanov, A.Y.; Vasilev, E.V.; Kozlova, N.P.; Shalavina, E.V. Background for introduction of BAT system in intensive dairy farming in Russia. In Engineering for Rural Development, Proceedings of the 17th International Scientific Conference, Jelgava, Latvia, 23-25 May 2018; LLU: Jelgava, Latvia, 2018; pp. 278-284. [CrossRef]

3. Briukhanov, A.Y.; Vasilev, E.V.; Kozlova, N.P.; Shalavina, E.V.; Subbotin, I.A.; Lukin, S.M. Environmental assessment of livestock farms in the context of BAT system introduction in Russia. J. Environ. Manag. 2019, 246, 283-288. [CrossRef] [PubMed]

4. Management Directive for Agro-Industrial Complex RD-APK 1.10.15.02-17 "Recommended Practice for Engineering Designing of Systems for Animal and Poultry Manure Removal and Pre-Application Treatment". Available online: https://docs.cntd.ru/ document/ 495876346 (accessed on 13 February 2021). (In Russian).

5. Information and Technical BAT Reference Book “Intensive Rearing of Pigs". 2017. Available online: http://www.burondt.ru/ NDT/NDTDocsDetail.php?UrlId=1138\&etkstructure_id=1872 (accessed on 10 April 2021). (In Russian).

6. Information and Technical BAT Reference Book “Intensive Rearing of Farm Poultry". 2017. Available online: http://www. burondt.ru/NDT/NDTDocsDetail.php?UrlId=1140\&etkstructure_id=1872 (accessed on 10 April 2021). (In Russian).

7. HELCOM Recommendation 28E/4. Annex III "Criteria and Measures Concerning the Prevention of Pollution from LandBased Sources" to Convention on the Protection of the Marine Environment of the Baltic Sea Area. 1992. Available online: https:/ /helcom.fi/about-us/convention/annexes-to-the-convention-2/annex-iii/ (accessed on 21 March 2021).

8. Bittman, S.; Dedina, M.; Howard, C.M.; Oenema, O.; Sutton, M.A. (Eds.) Options for Ammonia Mitigation: Guidance from the UNECE Task Force on Reactive Nitrogen; Centre for Ecology and Hydrology (CEH): Edinburgh, UK, 2014; 82p.

9. Santonja, G.G.; Georgitzikis, K.; Scalet, B.M.; Montobbio, P.; Roudier, S.; Delgado Sancho, L. Best Available Techniques (BAT) Reference Document for the Intensive Rearing of Poultry or Pigs; Publications Office of the European Union: Luxembourg, 2017; ISBN 978-92-79-70214-3.

10. Oenema, O.; Salomez, J.; Branquinho, C.; Budňáková, M.; Čermák, P.; Geupel, M.; Johnes, P.; Tompkins, C.; Spranger, T.; Erisman, J.W.; et al. Developing integrated approaches to nitrogen management. In The European Nitrogen Assessment; Sutton., M.A., Ed.; Cambridge University Press: Cambridge, NY, USA, 2011; pp. 541-550. [CrossRef]

11. Draft Guidance Document on Integrated Sustainable Nitrogen Management. In Proceedings of the Executive Body for the Convention on Long-Range Transboundary Air Pollution. Fortieth Session, Geneva, Switzerland, 17-18 December 2020; p. 200. Available online: http:/ / staging2.unece.org.net4all.ch/fileadmin/DAM/env/documents/2020/AIR/EB/ECE_EB.AIR_2020 _6-2008239E.pdf (accessed on 29 January 2021).

12. Zhang, X.; Davidson, E.A.; Zou, T.; Lassaletta, L.; Quan, Z.; Li, T.; Zhang, W. Quantifying nutrient budgets for sustainable nutrient management. Global. Biogeochem. Cycles 2020, 34, e2018GB006060. [CrossRef]

13. Oenema, O.; Brentrup, F.; Lammel, J.; Bascou, P.; Billen, G.; Dobermann, A.; Erisman, J.W.; Garnett, T.; Hammel, M.; Haniotis, T.; et al. Nitrogen Use Efficiency (NUE)—An Indicator for the Utilization of Nitrogen in Agriculture and Food Systems. EU Nitrogen Expert Panel; Wageningen University: Wageningen, The Netherlands, 2015; 47p. 
14. Oenema, O.; Brentrup, F.; Lammel, J.; Bascou, P.; Billen, G.; Dobermann, A.; Erisman, J.W.; Garnett, T.; Hammel, M.; Haniotis, T.; et al. Nitrogen Use Efficiency (NUE)_Guidance Document for Assessing NUE at Farm Level. EU Nitrogen Expert Panel; Wageningen University: Wageningen, The Netherlands, 2016; 49p.

15. Erisman, J.W.; Leach, A.; Bleeker, A.; Atwell, B.; Cattaneo, L.; Galloway, J. An Integrated Approach to a Nitrogen Use Efficiency (NUE) Indicator for the Food Production-Consumption Chain. Sustainability 2018, 10, 925. [CrossRef]

16. Hutchings, N.J.; Soerensen, P.; Cordovilc, C.M.d.S.; Leip, A.; Amon, B. Measures to increase the nitrogen use efficiency of European agricultural production. Glob. Food Secur. 2020, 26, 100381. [CrossRef]

17. Groenestein, C.M.; Hutchings, N.J.; Haenel, H.D.; Amon, B.; Menzie, H.; Mikkelsen, M.H.; Misselbrook, T.H.; van Bruggen, C.; Kupper, T.; Webb, J. Comparison of ammonia emissions related to nitrogen use efficiency of livestock production in Europe. J. Clean. Prod. 2019, 211, 1162-1170. [CrossRef] [PubMed]

18. De Klein, C.A.M.; Monaghan, R.M.; Alfaro, M.; Gourley, C.J.P.; Oenema, O.; Powell, J.M. Nitrogen performance indicators for dairy production systems. Soil Res. 2017, 55, 479-488. [CrossRef]

19. Quemada, M.; Lassaletta, L.; Jensen, L.S.; Godinot, O.; Brentrup, F.; Buckley, C.; Foray, S.; Hvid, S.K.; Oenema, J.; Richards, K.G.; et al. Exploring nitrogen indicators of farm performance among farm types across several European case studies. Agric. Syst. 2020, 177, 102689. [CrossRef]

20. Van Grinsven, H.; Erisman, J.W.; de Vries, W.; Lassaletta, L. Potential of Extensification of European and Dutch Agriculture for a More Sustainable Food System Focusing on Nitrogen and Livestock. In Just Enough Nitrogen; Sutton, M.A., Mason, K.E., Bleeker, A., Hicks, W.K., Masso, C., Raghuram, N., Reis, S., Bekunda, M., Eds.; Springer Nature Switzerland: Cham, Switzerland, 2020; pp. 83-101. [CrossRef]

21. Hong, B.; Swaney, D.P.; McCrackin, M.; Svanbäck, A.; Humborg, C.; Gustafsson, B.; Yershova, A.; Pakhomau, A. Advances in NANI and NAPI accounting for the Baltic drainage basin: Spatial and temporal trends and relationships to watershed TN and TP fluxes. Biogeochemistry 2017, 133, 245-261. [CrossRef]

22. Clair, T.A.; Pelletier, N.; Bittman, S.; Leip, A.; Arp, P.; Moran, M.D.; Dennis, I.; Niemi, D.; Sterling, S.; Drury, C.F.; et al. Interactions between reactive nitrogen and the Canadian landscape: A budget approach. Global. Biogeochem. Cycles 2014, 28, 1343-1357. [CrossRef]

23. Zhang, X.; Mauzerall, D.L.; Davidson, E.A.; Kanter, D.R.; Cai, R. The Economic and Environmental Consequences of Implementing Nitrogen-Efficient Technologies and Management Practices in Agriculture. J. Environ. Qual. 2015, 44, 312-324. [CrossRef] [PubMed]

24. Bauer, A. Status of Nutrient Bookkeeping in the Baltic Sea Countries; Umweltbundesamt: Dessau-Roßlau, Germany, 2015; 68p Available online: https://helcom.fi/media/publications/Status-of-nutrient-bookkeeping-in-the-Baltic-Sea-countries-1.pdf (accessed on 10 March 2021). (In German)

25. Wei, S.; Bai, Z.H.; Qinc, W.; Wub, Z.G.; Jiang, R.F.; Ma, L. Nutrient use efficiencies, losses, and abatement strategies for peri-urban dairy production systems. J. Environ. Manag. 2018, 228, 232-238. [CrossRef] [PubMed]

26. Unified Interdepartmental Information-Statistical System (UIIS). Available online: https://www.fedstat.ru/ (accessed on 18 January 2021). (In Russian).

27. On the State and Protection of the Environment of the Russian Federation in 2019; State Report; Ministry of Natural Resources and Environment of the Russian Federation: Moscow, Russia, 2020; p. 1000.

28. Sukhanov, P.A. Scientific Basis for Assessing and Managing the Agro-Resource Potential of the Region (on the Example of the Leningrad Region). Ph.D. Thesis, Agrophysical Research Institute, Saint Petersburg, Russia, 2013. Available online: www. agrophys.ru/Media/Default/Page/Dissertation\%20board/Avtoreferat_SukhanovPA.pdf (accessed on 23 March 2021).

29. Eurostat. Nutrient Budgets-Methodology and Handbook. Version 1.02. Eurostat and OECD, Luxembourg. 2013, p. 112. Available online: https:/ / ec.europa.eu/eurostat/documents/2393397/2518760/Nutrient_Budgets_Handbook_\%28CPSA_AE_109\%29 _corrected3.pdf/4a3647de-da73-4d23-b94b-e2b23844dc31 (accessed on 26 February 2021).

30. EUROSTAT. Glossary: Livestock Unit (LSU). Available online: https:/ / ec.europa.eu/eurostat/statistics-explained/index.php? title=Glossary:Livestock_unit_(LSU)\&oldid=16878 (accessed on 12 April 2021).

31. Guidelines for Balance Calculation of NPK, Humus and Calcium; TSINAO: Moscow, Russia, 2000; p. 40. (In Russian)

32. Briukhanov, A.Y.; Shalavina, E.V.; Vasilev, E.V. Methodology of integrated estimation of daily and annual output of animal/poultry manure. Dairy Newsl. 2014, 1, 78-85. (In Russian)

33. EMEP/EEA Emission Inventory Guidebook 2016. 3 B. Manure Management; European Environmental Agency; Publications Office of the European Union: Luxembourg, 2016. Available online: https://www.eea.europa.eu/publications/emep-eea-guidebook (accessed on 30 January 2021).

34. Briukhanov, A.; Kondratyev, S.; Tarbaeva, V.; Vorobyeva, E.; Oblomkova, N. Contribution of agricultural sources to nutrient load generated on the Russian part of the Baltic Sea catchment area. In Rural Development 2017: Bioeconomy Challenges, Proceedings of the 8th International Scientific Conference, Academia, Kaunas District, Lithuania, 23-24 November 2017; Raupeliene,, A., Ed.; Aleksandras Stulginskis University: Kaunas District, Lithuania, 2017; pp. 226-231. [CrossRef]

35. Roy, E.D.; Wagner, C.R.H.; Niles, M.T. Hot spots of opportunity for improved cropland nitrogen management across the United States. Environ. Res. Lett. 2021, 16, 035004. [CrossRef] 
36. Lehn, F.; Leitans, L.; Astover, A.; Eriksson, A.K.; Listh, U.; Salo, T.; Luostarinen, S.; Helin, J.; Lehtonen, E.; Wach, D.; et al. National Nutrient Balances in the Baltic Sea Region; Kuka, K., Ed.; Manure Standards Project of Interreg Baltic Sea Region; 2019; 67p. Available online: https://www.luke.fi/manurestandards/wp-content/uploads/sites/25/2019/12/National-nutrient-balancesin-the-Baltic-Sea-Region.pdf (accessed on 12 January 2021).

37. Wang, J.; Liu, Q.; Hou, Y.; Qui, W.; Lesschen, J.P.; Zhang, F.; Oenema, O. International trade of animal feed: Its relationships with livestock density and $\mathrm{N}$ and $\mathrm{P}$ balances at country level. Nutr. Cycl. Agroecosyst. 2018, 110, 197-211. [CrossRef]

38. Khazanov, E.E.; Gordeev, V.V.; Khazanov, V.E. Modernisation of Dairy Farms; SZNIIMESH Publ.: Saint Petersburg, Russia, 2008; 380p. (In Russian)

39. Popov, V.D.; Perekopskiy, A.N.; Akhmedov, M.S.; Terentiev, A.V. Methods and Technological Processes of Harvesting High-Quality Hay in Conditions of Increased Humidity; IEEP: Saint Petersburg, Russia, 2012; 72p. (In Russian)

40. McLellan, E.L.; Cassman, K.G.; Eagle, A.J.; Woodbury, P.B.; Sela, S.; Tonitto, C.; Marjerison, R.D.; van Es, H.M. The Nitrogen Balancing Act: Tracking the Environmental Performance of Food Production. BioScience 2018, 68, 194-203. [CrossRef] [PubMed]

41. Sundrum, A. Real-farming emissions of reactive nitrogen-Necessities and challenges. J. Environ. Manag. 2019, 240, 9-18. [CrossRef] [PubMed]

42. Kozlova, N.; Briukhanov, A.; Vasilev, E.; Shalavina, E. Environmental assessment of livestock farms in Russia. In Rural Developmexnt 2017: Bioeconomy Challenges, Proceedings of the 8th International Scientific Conference, Academia, Kaunas District, Lithuania, 23-24 November 2017; Raupelienè, A., Ed.; Aleksandras Stulginskis University: Kaunas District, Lithuania, 2017; pp. 330-336.

43. Briukhanov, A.; Dorokhov, A.; Shalavina, E.; Trifanov, A.; Vorobyeva, E.; Vasilev, E. Digital methods for agro-monitoring and nutrient load management in the Russian part of the Baltic Sea catchment area. IOP Conf. Ser. Earth Environ. 2020, 578, 2-6. [CrossRef]

44. Molinuevo-Salces, B.; Riaño, B.; Vanotti, M.B.; Hernández-González, D. Pilot-Scale Demonstration of Membrane-Based Nitrogen Recovery from Swine Manure. Membranes 2020, 10, 270. [CrossRef] [PubMed]

45. Finzi, A.; Mattachini, G.; Lovarelli, D.; Riva, E.; Provolo, G. Technical, Economic, and Environmental Assessment of a Collective Integrated Treatment System for Energy Recovery and Nutrient Removal from Livestock Manure. Sustainability 2020, $12,2756$. [CrossRef]

46. Provolo, G.; Mattachini, G.; Finzi, A.; Cattaneo, M.; Guido, V.; Riva, E. Global Warming and Acidification Potential Assessment of a Collective Manure Management System for Bioenergy Production and Nitrogen Removal in Northern Italy. Sustainability 2018, 10, 3653. [CrossRef] 